\title{
O AMBIENTE EMPRESARIAL ATUAL COMO LOCUS DO COMETIMENTO DE CRIMES
}

\section{THE CURRENT BUSINESS ENVIRONMENT AS A LOCAL CRIME COMMITMENT}

\section{HELENA KIRSCH WRANY}

Acadêmica do curso de Direito - Centro Universitário Curitiba - UNICURITIBA. Curitiba - PR. E-mail: helena.wrany@uol.com.br

\section{FÁBIO ANDRÉ GURAGNI}

Professor Doutor Orientador - Centro Universitário Curitiba - UNICURITIBA. Curitiba - PR. E-mail: guaragni@mppr.mp.br

\section{RESUMO}

O intuito do atual trabalho é perceber a razão da ocorrência dos delitos económicos e seus efeitos na atualidade. Para realizar a investigação foi utilizado como metodologia a pesquisa descritiva bibliográfica, por meio da pesquisa em bibliotecas, físicas e digitais, livros, artigos científicos, publicações em periódicos, boletins de faculdades, dissertações.

O primeiro momento da pesquisa foi dedicado a compreensão do surgimento dos delitos econômicos. Percebe-se que tanto a fragmentária e sectorial proteção dos direitos fundamentais de primeira dimensão por parte do Estado de Direito Liberal, quanto a tutela exacerbada de direitos fundamentais de segunda dimensão do Estado Social, compadeceram de fracasso. 
Personalidade Acadêmica Homenageada:

Raymundo Juliano Feitosa (Universidade Federal do Rio Grande do Norte - UFRN)

Como solução adveio uma via intermediária, o Estado Interventor (MARTINS; KNOERR, 2016, p. 357), cujo principal objetivo se fixava na justiça social, nomeadamente na esfera económico-social. Fato resultante numa obrigação positiva do Estado e, consequentemente, numa vasta malha de poderes sancionatórios (DIAS, 2012, p. 533), expandindo-se aos diversos campos do direito, mormente, o Direito Penal Econômico.

O campo do Direito Penal Econômico alçou ares de suma relevância a sociedade durante o século XXI, pelo desdobramento do fenômeno da globalizalização e pela "sociedade de risco".

Como resultado do estudo, conclui-se que inerente a sociedade atual, encontra-se a despacialização (GIDDENS, 2003, p. 168) e porosidade que a frenética interconectividade representa no estabelecimento de relações económicas, o que facilita ao ambiente mercatório o cometimento de crimes. Invoca-se a necessidade de uma intervenção transnacionalmente conectada e preparada para combater os abusos ou desvios à legitima atividade mercantil. A fluida e manifesta maleabilidade do capitalismo financeiro persuade os empresários na busca não apenas de uma manipulação espacial que Ihes conceda vantagem, mas de uma máscara de licitude que, de fachada, os permita manterem-se legitimados nas suas atuações.

No epicentro deste cenário encontra-se o envolvimento do funcionário destas empresas que, por vezes, ao refletirem o modo operacional dos seus superiores, ou até um compreensível desconhecimento da repercussão das ações por estes cometida, há o desvio cognitivo de sua conduta.

Ocorre também a situação em que certos empresários honestos se sentem compelidos a, em igual medida, adotar determinados comportamentos ilícitos, a fim de manter a competitividade das suas empresas no mercado, criando um verdadeiro efeito ressaca de proliferação da ilicitude.

No polo contrário desta equação, temos aqueles cujo raciocínio, para além de completar tanto o requisito cognitivo como volitivo, realizam uma análise de risco, não apenas de custo/beneficio entre a hipertrofiada margem económica e a eventual responsabilidade penal, como da inércia ou completa inação das dispersas vítimas 
Personalidade Acadêmica Homenageada:

Raymundo Juliano Feitosa (Universidade Federal do Rio Grande do Norte - UFRN)

que atingem. Fator comum a empregados e empresário é a difícil apuração da autoria e materialidade de sua conduta.

Como efeito dessa criminalidade, perpetuam-se os fenómenos geradores da putrefação de um seguimento mercantil, em que o não cumprimento legislativo tornase e uma praxe mercatória, que menospreza a lei, em prol dos desejos de determinados grupos atuantes no mercado.

Face a esse ambiente criminogêno, o empresário depara-se com um impasse relativo à redução de custos; uma moral, apontada pela alta economicidade, aproveitando-se do aumento tecnológico aliado à organização empresarial, e uma outra, imoral, adentrando na ilicitude, desrespeitando as regras trabalhistas e empresariais.

Apesar desse ambiente, principalmente em virtude das grandes investigações nessa área, houve uma pedagogia social, valorando o empresário que opta pelo caminho moral, e exclui do mercado consumidor aquele que não, contudo, tal construção moral ainda se encontra nas primeiras pedras desse caminho.

PALAVRAS-CHAVE: Iniciação Científica; Conlubradec; Crimes Econômicos.

\section{REFERÊNCIAS}

DIAS, Jorge Figueiredo. O direito penal entre o passado, presente e futuro. Revista portuguesa de ciência criminal, Coimbra, oㅡ22, p. 521 a 541, 2012.GIDDENS, Anthony. A Constituição da Sociedade. Trad. Álvaro Cabral. Martins Fontes, São Paulo, 2003. p. 168 e 170.

GIDDENS, Anthony. A Constituição da Sociedade. Trad. Álvaro Cabral. Martins Fontes, São Paulo, 2003.

MARTINS, José Alberto Monteiro, KNOERR, Fernando Gustavo. The police power and compliance in a legal state and their influence on the anti-corruption law (law 12,846 dated august 1, 2013). Revista Jurídica Unicuritiba. Curitiba, vol. 02, oㅡ 43, 2016. P 351-387. 